\title{
Tumor Necrosis Factor Downregulates Granulocyte-Colony-stimulating Factor Receptor Expression on Human Acute Myeloid Leukemia Cells and Granulocytes
}

\author{
Osama Elbaz, Leo M. Budel, Hans Hoogerbrugge, Ivo P. Touw, Ruud Delwel, Lotfy A. Mahmoud, and Bob Löwenberg \\ Dr. Daniel den Hoed Cancer Center, Rotterdam, The Netherlands; and Almansoura Faculty of Medicine, Almansoura, Egypt
}

\begin{abstract}
Tumor necrosis factor (TNF) inhibits granulocyte-colonystimulating factor (G-CSF)-induced human acute myeloid leukemia (AML) growth in vitro. Incubation of blasts from three patients with AML in serum-free medium with TNF $\left(10^{3} \mathrm{U} /\right.$ $\mathrm{ml}$ ), and subsequent binding studies using ${ }^{125} \mathrm{I}-\mathrm{G}-\mathrm{CSF}$ reveal that TNF downregulates the numbers of G-CSF receptors by $\sim 70 \%$. G-CSF receptor numbers on purified blood granulocytes are also downmodulated by TNF. Downregulation of GCSF receptor expression becomes evident within $10 \mathrm{~min}$ after incubation of the cells with TNF at $37^{\circ} \mathrm{C}$ and is not associated with an apparent change of the dissociation constant $\left(K_{d}\right)$. The TNF effect does not occur at $0^{\circ} \mathrm{C}$ and cannot be induced by IL-2, IL-6, or GM-CSF. TNF probably exerts its effect through activation of protein kinase $C(P K C)$ as the TNF effect on G-CSF receptor levels can be mimicked by 12-O-tetradecanoylphorbol-13-acetate. The PKC inhibitor Staurosporine (Sigma Chemical Co., St. Louis, MO) as well as protease inhibitors can completely prevent G-CSF receptor downmodulation. Thus, it appears TNF may act as a regulator of G-CSF receptor expression in myeloid cells and shut off G-CSF dependent hematopoiesis. The regulatory ability of TNF may explain the antagonism between TNF and G-CSF stimulation. (J. Clin. Invest. 1991. 87:838-841.) Key words: AML (cells) • granulocytes • TNF • downmodulation • PKC activation
\end{abstract}

\section{Introduction}

Tumor necrosis factor $\alpha(\mathrm{TNF} \alpha)^{1}$ is a nonglycosylated protein with a mol wt of 17,350 (1) synthesized by activated mononuclear phagocytes (2). It has an important role in regulating hematopoiesis. It may induce the release of certain hematopoietic growth factors from diverse cells, e.g., granulocyte macrophage-colony-stimulating factor (GM-CSF) (3) and granulocyte-colony-stimulating factor (G-CSF) (4) from human lung

Address reprint requests to Dr. Bob Löwenberg, Dr. Daniel den Hoed Cancer Center, Hematology Department, P. O. Box 5201, 3008 AE Rotterdam, The Netherlands. 1990

Received for publication I June 1990 and in revised form 3 October

1. Abbreviations used in this paper: AML, acute myeloid leukemia; CSF, colony-stimulating factor; G-CSF, granulocyte-CSF; GM-CSF, granulocyte macrophage-CSF; M-CSF, monocyte-CSF; PKC, protein kinase $\mathrm{C}$; TNF $\alpha$, tumor necrosis factor $\alpha$; TPA, 12-O-tetradecanoylphorbol-13 acetate.

J. Clin. Invest.

(c) The American Society for Clinical Investigation, Inc.

0021-9738/91/03/0838/04 \$2.00

Volume 87, March 1991, 838-841 fibroblasts, monocyte colony-stimulating factor (M-CSF) from human monocytes (5), and interleukin-1 from endothelial cells (6).

The role of G-CSF in controlling the survival, proliferation, differentiation, and functional activation of granulocytes and their precursors has been established (7). Further, G-CSF stimulates the proliferation of acute myeloid leukemia (AML) in culture (8-10) and it may also induce maturation of myeloid leukemia (11-13). In previous reports, it has been shown that TNF acts antagonistically with the proliferative effects of GCSF on AML blasts in vitro $(14,15)$, and thus appears to be a negative regulator of the G-CSF-induced proliferation of AML cells.

In this study we have addressed the question whether the mechanism of TNF suppression of G-CSF-mediated growth may occur at the level of G-CSF membrane receptors. The results of the experiments reported here show that TNF $\alpha$ downregulates G-CSF receptor expression on AML blasts, suggesting that the antagonistic effect of TNF is accomplished through G-CSF receptor downmodulation. A similar downregulation of G-CSF receptor expression is also evident when blood granulocytes are incubated with TNF. Additional experiments suggest that activation of protein kinase $C$ (PKC) and release of proteases that cleave off the receptors are crucial events in the rapid downregulation of G-CSF receptors.

\section{Methods}

Purification of AML blasts and normal granulocytes. AML cells were isolated from the peripheral blood and the bone marrow of eight adult untreated AML cases that were classified as M1 $(n=2), \mathrm{M} 2(n=1), \mathrm{M} 4$ $(n=2)$, and M5 $(n=3)(16,17)$. The AML cells were separated by Ficoll-Isopaque centrifugation and subsequent removal of E-rosetteforming cells (18), and then cryopreserved in 7.5\% DMSO and $20 \%$ inactivated FCS. The cell preparations were also depleted from monocytic cells by plastic adherence. The viability of the cells after thawing was always $>90 \%$. Morphological examination of cytospin slides of the thawed cells after depleting the monocytic fraction revealed that $\geq 98 \%$ of the cells were blasts. Normal peripheral blood granulocytes were obtained from the heparinized blood of healthy volunteers following sedimentation in $0.1 \%$ methylcellulose, and subsequent Ficoll-Isopaque centrifugation. The resultant cell fractions consisted of $92 \%-$ 96\% neutrophils, $2 \%-5 \%$ eosinophils, and $3 \%-5 \%$ monocytes/lymphocytes. The latter cell preparations were used fresh.

Hematopoietic growth factors. Recombinant human GM-CSF (a gift from Dr. S. Clark from Genetics Institute, Cambridge, MA) at 200 U/ml, IL-2 (Cetus Corp., Emeryville, CA) at 50 U/ml, IL-6 (Central Laboratory of the Netherlands Red Cross Blood Transfusion Service, Amsterdam) at $10^{3} \mathrm{U} / \mathrm{ml}$, and TNF $\alpha$ (Dr. Adolf, Boehringer Institute, Vienna, Austria) at $10^{3} \mathrm{U} / \mathrm{ml}$ were applied for incubation of cells prior to binding studies. These concentrations supported optimal AML cell proliferation under serum-free conditions $(10,11,15,19)$. Recombinant human G-CSF (Amgen Biologicals, Thousand Oaks, CA) was used for radiolabeling purposes. 
Treatment of the cells with 12-O-tetradecanoylphorbol-13-acetate (TPA), Staurosporine, and protease inhibitors. To study the mechanism of action of TNF, granulocytes were incubated in serum-free medium (SFM) for $60 \mathrm{~min}$ at $37^{\circ} \mathrm{C}$ with TPA (Sigma Chemical Co., St. Louis, MO) at $50 \mathrm{ng} / \mathrm{ml}$. The cells were pretreated with the protein kinase C (PKC) inhibitor Staurosporine (Sigma) at $0.1 \mu \mathrm{M}$. The cells ( 1 $\mathrm{ml}$ end vol) were also pretreated with $20 \mu \mathrm{l}$ mixture of protease inhibitors (mixture: $2 \%$ gelatin in $0.15 \mathrm{M} \mathrm{NaCl}, 1 \mathrm{mg} / \mathrm{ml}$ Aprotinin, $1 \mathrm{mg} / \mathrm{ml}$ Leupeptin, $1 \mathrm{mg} / \mathrm{ml}$ iodoacetamide, $1 \mathrm{mg} / \mathrm{ml}$ Bacitracin, and $1 \mathrm{mM}$ PMSF). This pretreatment was applied $30 \mathrm{~min}$ before the direct addition of TNF or TPA.

Preincubation of the cells with TNF. Before the binding experiments, the AML cells or granulocytes were washed twice in HBSS, then incubated in SFM (20) for $10-60 \mathrm{~min}$ at $37^{\circ} \mathrm{C}$, without or with TNF $\left(10^{3} \mathrm{U} / \mathrm{ml}\right)$. Finally, the cells were washed twice in HBSS to remove residual TNF.

Binding of radiolabeled G-CSF to AML blasts and granulocytes. Purified rhG-CSF was radiolabeled according to the method of Bolton and Hunter (21) as described (22). Radiolabeling of rhG-CSF resulted in a protein that had a specific binding capacity of $50-60 \%$, and a sp act of $20,000 \mathrm{cpm} / \mathrm{ng}$. The cells $\left(4-8 \times 10^{6}\right.$ per point) were incubated for 1 $\mathrm{h}$ at $37^{\circ} \mathrm{C}$ in $100 \mu \mathrm{l} \alpha$-minimal essential medium with $10 \% \mathrm{FCS}$ and with 1 and $2 \mathrm{nmol} /$ liter ${ }^{125} \mathrm{I}-\mathrm{G}-\mathrm{CSF}$ (for preliminary binding estimations) or $20-4,000 \mathrm{pmol} / \mathrm{liter}{ }^{125} \mathrm{I}$-G-CSF (for the complete binding assay) in the presence or absence of excess nonlabeled G-CSF (i.e., 200 $\mathrm{nmol} /$ liter) exactly as described (22). Specific binding was determined as the difference between the amount of radioactivity bound in the absence, and the amount of radioactivity bound in the presence of nonlabeled G-CSF. Experiments were conducted in duplicate. Receptor numbers and binding affinity were derived following Scatchard analysis (23). In calculations, the maximal binding capacity was used to correct for the free counts.

\section{Results}

$T N F$ downregulates the number of high affinity $G$-CSF receptors on $A M L$ blasts. In previous experiments (22), we have demonstrated that AML blasts frequently show low levels of specific binding of ${ }^{125} \mathrm{I}-\mathrm{G}-\mathrm{CSF}$, so that in practice it is difficult to assess a suppressive TNF effect on G-CSF receptor expression. The cells from cases 1,2 , and 3 were selected for the complete binding studies because of relatively high G-CSF spe-
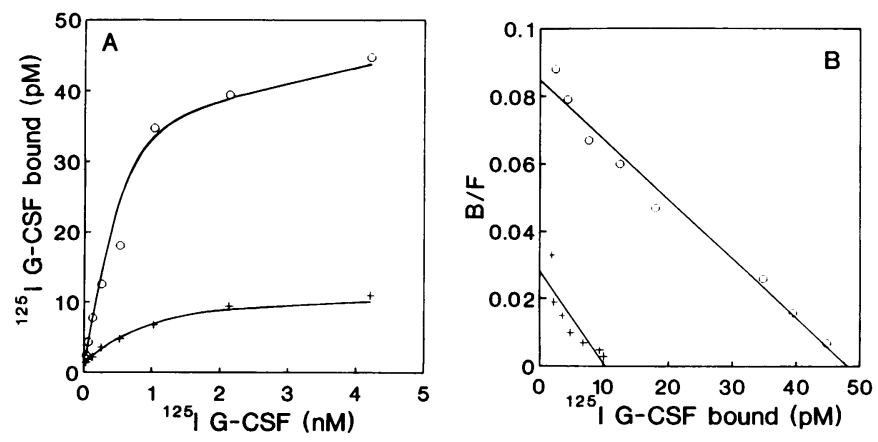

Figure 1. Downregulation of ${ }^{125}$ I-G-CSF specific binding to AML cells by TNF. $(A)$ Labeling curve: Cells $\left(4.9 \times 10^{6}\right)$ of AML case 1 were preincubated with $(+)$ or without $(0)$ TNF $\left(10^{3} \mathrm{U} / \mathrm{ml}\right)$ in serum-free medium for $1 \mathrm{~h}$, and then subjected to radioreceptor studies with titrated concentrations of ${ }^{125} \mathrm{I}-\mathrm{G}-\mathrm{CSF}$ as described in Methods. Labeling curves have been corrected for nonspecific binding. $(B)$ Scatchard plots of ${ }^{125}$ I-G-CSF binding to AML cells, i.e., with $(+)$ or without (O) TNF. Each point represents the mean of duplicate estimations.
Table I. Effect of TNF on Binding of ${ }^{125} I-G-C S F$ to AML Blasts

\begin{tabular}{cccccc}
\hline & \multicolumn{2}{c}{ Without TNF } & & \multicolumn{2}{c}{ With TNF } \\
\cline { 6 - 6 } Case no. & $\begin{array}{c}\text { Receptors } \\
\text { per cell }\end{array}$ & \multicolumn{1}{c}{$K_{\mathrm{d}}$} & & $\begin{array}{c}\text { Receptors } \\
\text { per cell }\end{array}$ & $K_{\mathrm{d}}$ \\
\hline & & $p m o l /$ liter & & $p m o l /$ liter \\
1 & $577 \pm 48$ & $546 \pm 106$ & $123 \pm 37$ & $357 \pm 64$ \\
2 & $357 \pm 65$ & $472 \pm 83$ & $114 \pm 28$ & $302 \pm 46$ \\
3 & $243 \pm 18$ & $386 \pm 129$ & $96 \pm 21$ & $317 \pm 93$
\end{tabular}

Receptor numbers (mean per cell $\pm \mathrm{SD}$ ) and $K_{\mathrm{d}}($ mean $\pm \mathrm{SD})$ were derived from binding experiments and subsequent analysis according to Scatchard. Aspirated bone marrow cells $\left(2-5 \times 10^{6}\right)$ were obtained from three cases with AML and used, in duplicate, for each point of analysis.

cific binding as became evident from preliminary ${ }^{125} \mathrm{I}-\mathrm{G}-\mathrm{CSF}$ binding experiments (data not shown).

Complete binding assays with titrated concentrations of ${ }^{125}$ I-G-CSF and subsequent Scatchard analysis for cases 1 (Fig. 1), 2 , and 3 revealed that TNF reduced the average numbers of G-CSF receptors on the cells of the three cases by $\sim 70 \%$ (Table I). To exclude the possibility that these effects were caused by direct competition between TNF and G-CSF, specific binding of ${ }^{125} \mathrm{I}-\mathrm{G}-\mathrm{CSF}$ to AML blasts (case 1) was determined in the presence of excess TNF $(400 \mathrm{nmol} /$ liter $)$ at $0^{\circ} \mathrm{C}$ for $6 \mathrm{~h}$. Under these conditions, TNF did not inhibit specific binding of ${ }^{125} \mathrm{I}$ G-CSF.

$T N F$ downregulates the number of high affinity G-CSF receptors on blood granulocytes. In comparison, we have also determined the effect of TNF on G-CSF receptor expression on granulocytes. Preliminary ${ }^{125}$ I-G-CSF binding experiments using granulocytes from the blood of four donors demonstrated that preincubation with TNF reduced specific binding of ${ }^{125} \mathrm{I}$ G-CSF by $70-90 \%$. Complete binding experiments (Fig. 2) revealed that TNF reduced the numbers of G-CSF receptors on granulocytes from $1,969 \pm 186$ per cell $\left(K_{\mathrm{d}} 667 \pm 109 \mathrm{pmol} / \mathrm{liter}\right)$ to $342 \pm 47$ per cell ( $\left.K_{\mathrm{d}} 638 \pm 76 \mathrm{pmol} / \mathrm{liter}\right)$. The downregulatory effect of TNF was already apparent within $10 \mathrm{~min}$ after addition of TNF to granulocytes (Fig. $3 A$ ). This inhibitory effect did not become apparent when the cells were incubated under identical conditions with other recombinant cytokines, i.e., IL-2, IL-6, GM-CSF (Fig. 3 B).
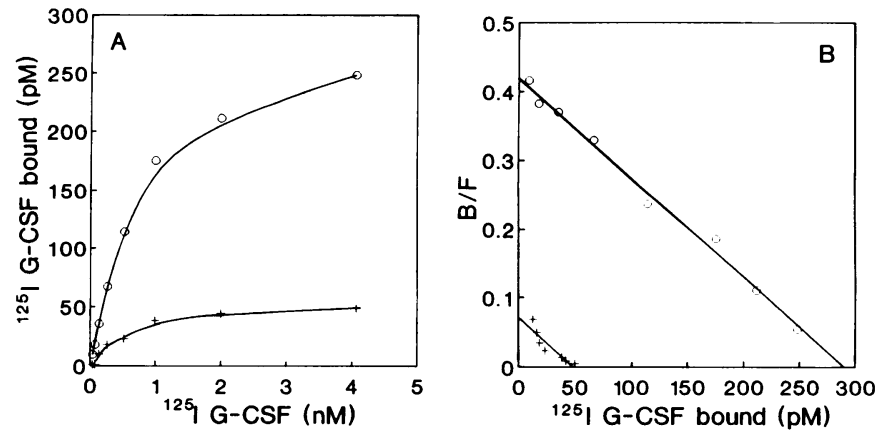

Figure 2. Downregulation of ${ }^{125} \mathrm{I}-\mathrm{G}-\mathrm{CSF}$ specific binding to granulocytes by TNF. Granulocytes $\left(8.8 \times 10^{6}\right)$ were incubated with $(+)$ or without (O) TNF $\left(10^{3} \mathrm{U} / \mathrm{ml}\right)$ for $1 \mathrm{~h}$. For explanation see Fig. 1. 

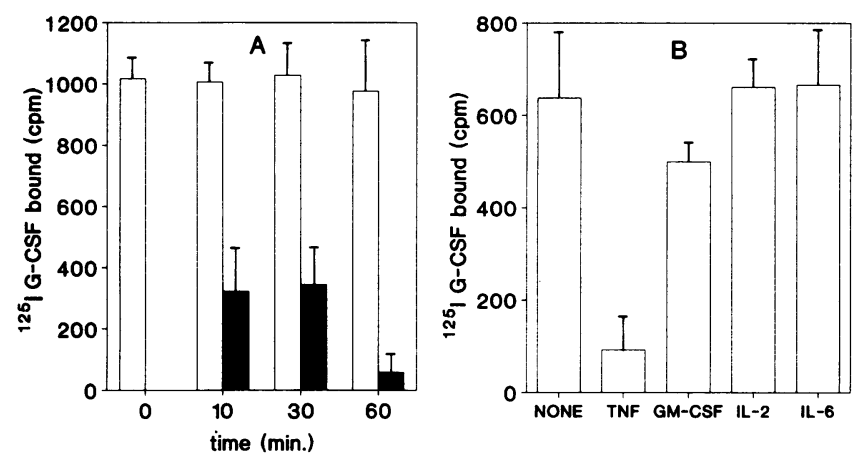

Figure 3. $(A)$ Downregulation of G-CSF receptors by TNF as a function of time. Granulocytes $\left(3 \times 10^{6}\right)$ were incubated with (solid bars) or without (open bars) TNF $\left(10^{3} \mathrm{U} / \mathrm{ml}\right)$ for $0,10,30$, or $60 \mathrm{~min}$. Specific binding of ${ }^{125} \mathrm{I}-\mathrm{G}-\mathrm{CSF}$ (using $1 \mathrm{nmol} / \mathrm{liter}{ }^{125} \mathrm{I}-\mathrm{G}-\mathrm{CSF}$ ) was subsequently determined as described in Methods. Values have been corrected for nonspecific binding and represent the means of triplicate estimations in cpm \pm SD. $(B)$ Downregulation of G-CSF receptors: specific ability of TNF. Granulocytes $\left(2 \times 10^{6}\right)$ were incubated with TNF and comparative cytokines, i.e., GM-CSF, IL-2, and IL-6, for $1 \mathrm{~h}$ at $37^{\circ} \mathrm{C}$ and specific G-CSF binding was assessed (see $A$ ).

$G-C S F$ receptor downregulation dependent on protein $k i-$ nase $C$. G-CSF receptor downregulation could also be achieved following exposure of granulocytes to the PKC activator TPA (Fig. 4). Complete binding experiment (Fig. 5) using titrated concentrations of ${ }^{125} \mathrm{I}-\mathrm{G}-\mathrm{CSF}$ revealed that TPA reduced the numbers of G-CSF receptors on granulocytes from $1,332 \pm 124$ per cell $\left(K_{\mathrm{d}} 614 \pm 98 \mathrm{pmol} / \mathrm{liter}\right)$ to $487 \pm 53$ per cell $\left(K_{\mathrm{d}} 645 \pm 132\right.$ $\mathrm{pmol} / \mathrm{liter})$. To further investigate whether the mechanism of action of TNF might depend on activation of PKC, we have determined the effect of TNF or TPA (PKC activator) on specific binding of ${ }^{125} \mathrm{I}-\mathrm{G}-\mathrm{CSF}$ to granulocytes following pretreatment with Staurosporine (PKC inhibitor). Staurosporine reversed the inhibitory effect of both TNF and TPA (Fig. 4). A cocktail of protease inhibitors could also abolish the effect of TNF under the same conditions (Fig. 4).

\section{Discussion}

This study was carried out to investigate the possibility that antagonistic effects between TNF and G-CSF on AML cell proliferation are accomplished at the level of G-CSF mem-

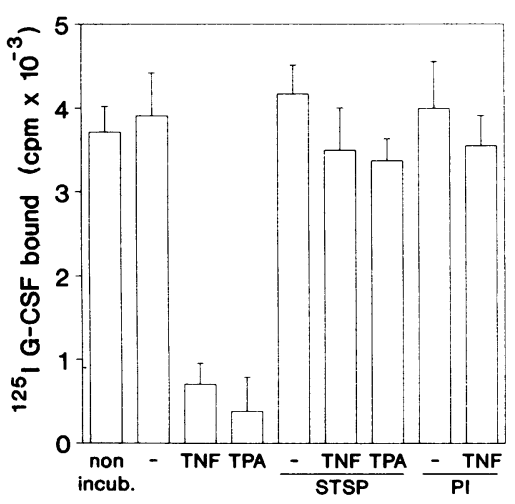

Figure 4. Downregulation of G-CSF receptors: effect of TPA, Staurosporine, and protease inhibitors. Granulocytes $\left(5 \times 10^{6}\right)$ were incubated with no supplement $(-)$, Staurosporine $(S T S P)(0.1 \mu \mathrm{M})$, or protease inhibitors $(P I)$ for $30 \mathrm{~min}$ at $37^{\circ} \mathrm{C}$. Then, TNF $\left(10^{3} \mathrm{U} / \mathrm{ml}\right)$ or TPA $(50 \mathrm{ng} / \mathrm{ml})$ was added for $60 \mathrm{~min}$ at $37^{\circ} \mathrm{C}$. The specific

binding of ${ }^{125} \mathrm{I}-\mathrm{G}-\mathrm{CSF}$ was assessed (see Fig. $3 \mathrm{~A}$ ). A control experiment was also done with nonincubated cells.
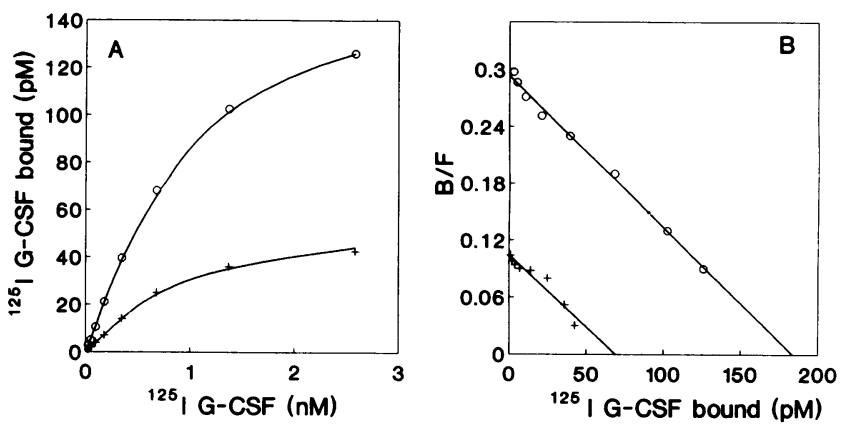

Figure 5. Downregulation of ${ }^{125} \mathrm{I}-\mathrm{G}-\mathrm{CSF}$ specific binding to granulocytes by TPA. Granulocytes $\left(8.3 \times 10^{6}\right)$ were incubated with $(+)$ or without (O) TPA $(50 \mathrm{ng} / \mathrm{ml})$ for $1 \mathrm{~h}$, and then subjected to radioreceptor studies. For explanation see Fig. 1.

brane receptors. The results reveal that incubation of the cells with TNF decreases G-CSF receptor numbers both on AML blasts and blood granulocytes considerably, i.e., by $\sim 70 \%$ of the initial mean receptor number. Suppression of G-CSF receptor binding by TNF could not be attributed to direct cross competition between G-CSF binding and TNF binding because this phenomenon does not occur at $0^{\circ} \mathrm{C}$. It is likely that the negative effect of TNF on the level of G-CSF receptor expression may contribute to the antagonistic relationship between the two factors. A reduction of the mean receptor density on the cells may reflect the loss of receptors of a proportion of G-CSF reactive cells and thus these cells may become nonresponsive to G-CSF. The loss of G-CSF stimulability of AML blasts and granulocytes as controlled by TNF may represent an important regulatory function in hematopoiesis $(24,25)$.

G-CSF receptor downregulation by TNF can be characterized by the following features: G-CSF surface receptors disappear relatively rapidly (within $10 \mathrm{~min}$ ), suppression occurs at $37^{\circ} \mathrm{C}$, but not at $0^{\circ} \mathrm{C}$, maximal suppression is attained at 60 min (data not shown), and finally it involves a loss of G-CSF binding sites without an apparent change in receptor affinity. The fact that the reduction in G-CSF receptor density by TNF in AML cells and granulocytes is not complete $(70 \%)$, raises the possibility of functionally different subsets of G-CSF receptors. We have found that TPA can also downregulate G-CSF receptors under the same conditions (Fig. 4) and that the G-CSF receptor inhibitory effect due to TNF or TPA can be reversed by Staurosporine (PKC inhibitor) or protease inhibitors (Fig. 4). It is possible that in analogy with the observation of Downing et al. (26), who showed that the M-CSF receptor is downmodulated by its ligand as well as by TPA, TNF acts through activation of PKC. PKC, in turn, activates the release of proteases that specifically cleave off the ligand-binding domain from the receptor.

It remains unclear what the physiological significance of receptor downregulation by TNF in AML cells is. However, it is conceivable that a higher concentration of G-CSF is required to excite the same number of receptors after TNF exposure, and thereby rendering the cells less susceptible to G-CSF. The fact that TNF upregulates on the same cell type, receptors for IL-3 and GM-CSF (both early acting factors) (27) suggests that TNF acts as a response modulator. By increasing the susceptibility for IL-3 and GM-CSF and at the same time decreasing the susceptibility for G-CSF, TNF elicits a more immature response pattern to these three CSFs. 
The observation that the survival of neutrophils in vitro can be increased by G-CSF (28) is interesting in view of the downregulation of G-CSF receptors on neutrophils by TNF. Possibly TNF acts as a shut-off signal for granulocytes in circulation. However, more research needs to be done to elucidate the biological meaning of this phenomenon.

\section{Acknowledgments}

The authors wish to thank A. Sugiarsi and M. Drinkwaard for typing the manuscript, $H$. Vuik and S. Sliva for preparing the photographs, and Amgen for providing G-CSF.

This work was supported by the Dutch Cancer Society Koningin Wilhelmina Fonds.

\section{References}

1. Aggarwal, B. B., W. J. Koher, P. E. Hass, B. Moffat, S. A. Spencer, W. J. Henzel, T. S. Bringman, G. E. Nedwin, D. V. Goeddel, and R. N. Horkins. 1985 Human tumour necrosis factor: production, purification, and characterization. $J$. Biol. Chem. 260:2345-2354.

2. Carswell, E. A., L. J. Old, R. L. Kassel, S. Green, N. Fiore, and B. Williamson. 1975. An endotoxin-induced serum factor that causes necrosis of tumors. Proc. Natl. Acad. Sci. USA. 72:3666-3671.

3. Munker, R., J. Gassen, M. Ogawa, and H. P. Koeffler. 1986. Recombinant human TNF induces production of GM-CSF. Nature (Lond.). 323:79-82.

4. Koeffler, H. P., J. Gassen, J. Ranyard, L. Sonza, M. Shepard, and R. Munker. 1987. Recombinant human TNF $\alpha$ stimulates production of G-CSF. Blood. 70:55-59.

5. Oster, W., A. Lindermann, S. Horn, R. Mertelsmann, and F. Herrmann 1987. TNF-alpha but not TNF-beta induces secretion of colony stimulating factor for macrophages (CSF-1) by human monocytes. Blood. 70:1700-1706.

6. Nawroth, P. P., and D. M. Stern. 1986. Modulation of endothelial cell homostatic properties by tumor necrosis factor. J. Exp. Med. 163:740-745.

7. Nicola, N. A. 1987. Granulocyte colony-stimulating factor and differentiation-induction in myeloid leukemic cells. Int. J. Cell Cloning. 5:1-15.

8. Vellenga, E., D. C. Young, K. Wagner, D. Wiper, D. Ostapovicz, and J. D. Griffin. 1987. The effects of GM-CSF and G-CSF in promoting growth of clonogenic cells in acute myeloblastic leukemia. Blood. 69:1771-1776.

9. Vellenga, E., D. Ostapovicz, B. O'Rourke, and J. D. Griffin. 1987. Effects of recombinant growth factors, IL-3, GM-CSF and G-CSF on proliferation of leukemic cells in short-term and long-term cultures. Leukemia (Baltimore). 1:584589.

10. Delwel, R., M. Salem, C. Pellens, L. Dorssers, G. Wagemaker, S. Clark, and B. Löwenberg. 1988. Growth regulation of human acute myeloid leukemia. Effects of five recombinant hematopoietic factors in a serum free culture system. Blood. 72:1944-1949.

11. Salem, M., R. Delwel, L. A. Mahmoud, S. Clark, E. M. Elbasousy, and B. Löwenberg. 1989. Maturation of human acute myeloid leukemia in vitro: the response to five recombinant hematopoietic factors in serum free system. $\mathrm{Br}$. $J$. Haematol. 71:363-370.

12. Souza, L. M., T. C. Boone, J. Gabrilove, P. H. Lai, K. M. Zsebo, D. C. Murdoch, V. R. Chazin, J. Bruszewski, H. Lu, K. K. Chen, et al. 1986. Recombinant human granulocyte colony-stimulating factor: effects on normal and leukemic myeloid cells. Science (Wash. DC). 32:61-65.

13. Löwenberg, B., M. Salem, and R. Delwel. 1988. Effects of recombinant multi-CSF, GM-CSF, G-CSF and M-CSF on the proliferation and maturation of human AML in vitro. Blood Cells (Berl.). 14:539-549.

14. Hoang, T., B. Levy, N. Onetto, A. Haman, J. C. Rodriquez-Cimadevilla. 1989. Tumor necrosis factor $\alpha$ stimulates the growth of the clonogenic cells of acute myeloblastic leukemia in synergy with granulocyte/macrophage colonystimulating factor. J. Exp. Med. 170:15-26.

15. Salem, M., R. Delwel, I. Touw, L. A. Mahmoud, E. M. Elbasousy, and B. Löwenberg. 1990. Modulation of colony stimulating factor (CSF)-dependent growth of acute myeloid leukemia by tumor necrosis factor. Leukemia (Baltimore). 4:37-43.

16. French-American-British (FAB) Cooperative Group. 1976. Proposals for the classification of the acute leukemias. Br. J. Haematol. 33:451-458.

17. French-American-British (FAB) Cooperative Group. 1985. Proposals for the classification of the acute leukemias. Ann. Intern. Med. 103:620-625.

18. Böyum, A. 1968. Separation of leukocytes from blood and bone marrow. Scand. J. Clin. Lab. Invest. 21:77-89.

19. Nagata, S., M. Tsuchiya, S. Asano, Y. Kaziro, T. Yamazaki, O. Yamamoto, Y. Hirata, N. Kubota, M. Oheda, H. Nomura, and M. Ono. 1986. Molecular cloning and expression of cDNA for human granulocyte colony-stimulating factor. Nature (Lond.). 319:415-418.

20. Salem, M., R. Delwel, I. Touw, L. Mahmoud, and B. Löwenberg. 1988. Human AML colony growth in serum free culture. Leuk. Res. 12:157-165.

21. Bolton, A. E., and W. M. Hunter. 1973. The labelling of proteins to high specific radioactivities by conjugation to a ${ }^{125} \mathrm{I}$-containing acylating agent: application to the radio-immunoassay. Biochem. J. 133:529-539.

22. Budel, L. M., I. P. Touw, R. Delwel, and B. Löwenberg. 1989. Granulocyte colony-stimulating factor receptors in human acute myelocytic leukemia. Blood. 74:2668-2673.

23. Scatchard, G. 1949. The attraction of proteins for small molecules and ions. Ann. NY Acad. Sci. 51:660-672.

24. Murase, T., T. Hotta, H. Saito, and R. Ohno. 1987. Effect of recombinant human tumor necrosis factor on the colony growth of human leukemia progenitor cells and normal hematopoietic progenitor cells. Blood. 69:467-472.

25. Digel, W., M. Stefanic, W. Schöniger, C. Buck, A. Raghavachar, N. Frickhofen, H. Heimpel, and F. Porzsolt. 1989. Tumor necrosis factor induces proliferation of neoplastic B cells from chronic lymphocytic leukemia. Blood. 73:12421246.

26. Downing, J. R., M. F. Roussel, and C. J. Sherr. 1988. Ligand and proteinkinase $\mathrm{C}$ downmodulate the colony-stimulating factor 1 receptor by independent mechanisms. Mol. Cell. Biol. 9:2890-2896.

27. Elbaz, O., L. M. Budel, H. Hoogerbrugge, I. P. Touw, R. Delwel, M. Lofty, and B. Löwenberg. 1991. Tumor necrosis factor regulates the expression of granulocyte colony stimulating factor and interleukin-3 receptors on human acute myeloid leukemia cells. Blood. In press.

28. Begley, C. G., A. F. Lopez, N. A. Nicola, D. J. Warren, M. A. Vadas, C. J. Sanderson, and D. Metcalf. 1986. Purified colony-stimulating factors enhance the survival of human neutrophils and eosinophils in vitro. A rapid and sensitive microassay for colony-stimulating factors. Blood. 68:162-166. 